\title{
THE INFLUENCE OF PSYCHOCURATIVE ON CORTISOL LEVEL, ANXIETY, AND QUALITY OF LIFE IN ADVANCED STAGE CERVICAL CANCER PATIENTS
}

\author{
Soetrisno $^{1}$, Sri Mulyani ${ }^{2}$, Angesti Nugraheni ${ }^{2}$, Hafi Nurinasari ${ }^{1}$, Erindra Budi ${ }^{2}$ \\ ${ }^{1}$ Department of Obstetrics and Gynecology, Medical Faculty, Sebelas Maret University, Surakarta, Indonesia, \\ ${ }^{2}$ Midwifery Diploma IV, Medical Faculty, Sebelas Maret University, Surakarta, Indonesia
}

\begin{abstract}
Every year, there are 500.000 new cases and more than 250.000 deaths caused by cervical cancerworldwide. Cervical cancer patients faced physical and psychological problems several times that it activate stress mechanism such as hypothalamus-pituitaryadrenal (HPA) axis. These recurrent activations caused HPA axis disruption and adverse clinical effects. Several symptoms of endocrine stress response are the change of circadian cortisol rhythm. Cortisol is known as a stress hormone that involves an organism's response to stress and anxiety that influence the quality of life. This research aims to analyze the differences among serum cortisol level, anxiety, and quality of life in cervical cancer patients before and after psychocurative intervention in obstetrics and gynecology wards and polyclinic in RSUD Dr. Moewardi Surakarta. This research is an experimental double-blind randomized controlled clinical trial pre-test post-test group design study. The subjects were advance stage (IIB-IV)cervical cancer patients. The subjects were randomly chosen into fifteen subjects that given standard therapy and psychocurative, while the other fifteen subjects as a control only got standard therapy. Data were obtained from measurement of serum cortisol level, anxiety questionnaire DASS 42 and WHO quality of life questionnaire. Data were analyzed using SPSS 21 using difference test. The difference mean test result of cortisol serum level, anxiety, quality of life from the controlled group and uncontrolled group showed a significant difference ( $p<$ 0.05). In conclusion, psychocurative is significant to reduce cortisol level, anxiety, and improve the quality of life in advanced stage cervical cancer patients.
\end{abstract}

Keywords: Psychocurative; cortisol; anxiety; quality of life

\section{ABSTRAK}

Setiap tahun, di dunia terdapat 500.000 kasus baru dan lebih dari 250.000 kematian akibat kanker serviks. Pasien kanker serviks berulang kali menghadapi beban fisik dan psikis yang mengaktifkan mekanisme respon stress berupa aksis hipotalamus-pituitariadrenal (HPA). Aktivasi berulang tersebut dapat menimbulkan gangguan aksis HPA dan konsekuensi klinis yang merugikan. Beberapa tanda gangguan dalam sistem respon stress endokrin adalah perubahan ritme kortisol sirkadian. Kortisol yang dikenali sebagai hormon stress terlibat dalam respon organisme terhadap stress dan kecemasan serta berdampak pada kualitas hidup (quality of live). Tujuan penelitian ini menganalisis perbedaan kadar kortisol serum, kecemasan dan kualitas hidup pasien kanker serviks sebelum dan setelah intervensi psikokuratif di bangsal dan poliklinik kebidanan dan penyakit kandungan RSUD Dr. Moewardi Surakarta. Penelitian ini merupakan penelitian Experimental double blind randomized clinical trial pre-test post-test group design. Subjek adalah pasien kanker serviks stadium lanjut (IIB-IV). Dipilih secara acak lima belas subjek mendapat terapi standart dan psikokuratif, lima belas lainnya sebagai kontrol hanya mendapat terapi standart. Data diperoleh dengan cara pengukuran kadar kortisol serum, kuesioner kecemasan DASS 42, dan kuesioner quality of live menurut WHO. Data dianalisis dengan SPSS 21 dengan uji beda. Hasil uji beda rerata kadar kortisol serum, kecemasan, kualitas hidup kelompok perlakuan dan kontrol, menunjukkan perbedaan bermakna ( $p<0.05$ ). Sebagai simpulan psikokuratif secara bermakna menurunkan kadar kortisol, kecemasan, dan meningkatkan kualitas hidup pasien kanker serviks stadium lanjut

Kata kunci: Psikokuratif; kortisol; kecemasan; kualitas hidup

Correspondence: Soetrisno, Department of Obstetrics and Gynecology, Medical Faculty of Sebelas Maret University/Doctor Moewadi Hospital, Surakarta. E-mail: soetrisno_spogk@yahoo.com

pISSN:2355-8393 • eISSN: 2599-056x • doi: http://dx.doi.org/10.20473/fmi.v55i3.15502

- Fol Med Indones. 2019;55:202-205 • Received 15 Nov $2018 \bullet$ Accepted 4 Apr 2019

- Open access under CC-BY-NC-SA license • Available at https://e-journal.unair.ac.id/FMI/ 


\section{INTRODUCTION}

Cancer is the fifth leading cause of death in Indonesia. More than $40 \%$ of malignancy in women is gynecology cancer. The most common cases of gynecology cancer are cervical cancer, followed by ovary cancer, and uterine cancer. The peak incidence age of cervical cancer is 45-54 years. The five-year survival rate of cervical cancer stage I, II, III, IV are 50\%, 40\%, 20\%, and $0 \%$ (Azis, 2009). Every year, there are 500.000 new cases and more than 250.000 deaths caused by cervical cancer worldwide. In Indonesia that has 220 million population, there are 52 million women who are in risk for cervical cancer (Rasjidi, 2009).

In advance stage cervical cancer patients, stress occurs whether biological (progressivity and therapy), psychological (anxiety related to diagnosis, prognosis, medical costs, fear of death), social stress (family, economy, and environment). Long-term and repeated stressors can lead to a dangerous risk of depression. Approximately, $70 \%$ of advanced stage cervical cancer patients show changes in circadian profile into flat, consistent in high level, or erratic fluctuations (Sephton, 2000).

Many studies aimedon reducing the stress to improve quality of life and endurance in cervical cancer patients, based on the theory about the relationship between psychological factors and immune system function, blood vessel growth, and tumor development (Schettler, 2013; Soetrisno, 2009). Based on those theories, this study was conducted whether psychocurative interventions (cognitive, social, spiritual and physical) can help to reduce cortisol level that impacts to inhibit recurrence, reduce anxiety and improve the quality of life for cervical cancer patients.

Psychocurative is a treatment that aims to ensure that a person has a better chance to adapt to their psychological conditions and situations, also build harmonious and integral relationships to improve psychological stability and life skills. Psychocurative consists of cognitive, spiritual, social, and physical support that is expected to change distress conditions into eustress (Soetrisno, 2009).

\section{MATERIALS AND METHODS}

This research used experimental double-blind randomized clinical trial pre-test post-test group design. The subject of this research is advanced cervical cancer stage patients (IIB-IV) who treated in RSUD Dr. Moewardi Surakarta. Inclusion criterias: diagnosed with cervical cancer stage IIB-IV, able to speak Indonesian, able to communicate well, graduated at least from elementary school, willing and has already signed the consent in this research. Exclusion criterias: suffering another cancer other than cervix, pregnant women, having endocrine disorders, suffering severe mental disorders (psychotic), and history of depression treatment.

Thirty subjects who met inclusion and exclusion criteria were divided into two groups randomly. The treatment group was given to psychocurative in addition to standard therapy in four meetings, for each one 60 minutes every Monday in September 3rd, 10th, 17th, and the 24th year 2018. In the end of every psychocurative session, there were discussion and exploration about the experience that patient had during the previous psychocurative.In addition, the subjects performed an individual psychocurative three times a week at home with a psychocurative guide book that the researcherhad been created and given by. Researchers visit each subject's house once a week in order to monitor and motivate the subject as well to discuss and explore things related to the research and previous psychocurative.

The control group wasonly given standard therapy/ chemoradiation, which is done on different time with the treatment group in order to not violate ethics and respect patients' rights to get comprehensive services according to standard hospitals.

Before and after psychocurative intervention, the subject in treatment and control groups were measured their cortisol level in Laboratorium Klinik Prodia Surakarta at $06.00 \mathrm{WIB}$ as this hormone is constant in the morning before starting their activity. After that, anxiety was measured using DASS 42 , and the quality of life was measured using WHO questionnaire.The obtained data were analyzed using SPSS 21 using different test method.

\section{RESULTS}

As seen in Fig. 1, the average of cortisol in the treatment group is decreased about 5.19 after psychocurative intervention, while in control group has decreased into 1.07. The average of anxiety in the treatment group is decreased about 18.0 after psychocurative intervention, while in the control group decreased into 8.74. The average quality of life in the treatment group is increased after psychocurative intervention about 7.61, while in control group is constant. Whereas, the result of different mean scores of blood cortisol serum level, anxiety, quality of life between treatment and control group showed significant differences $(p<0.05)$. 


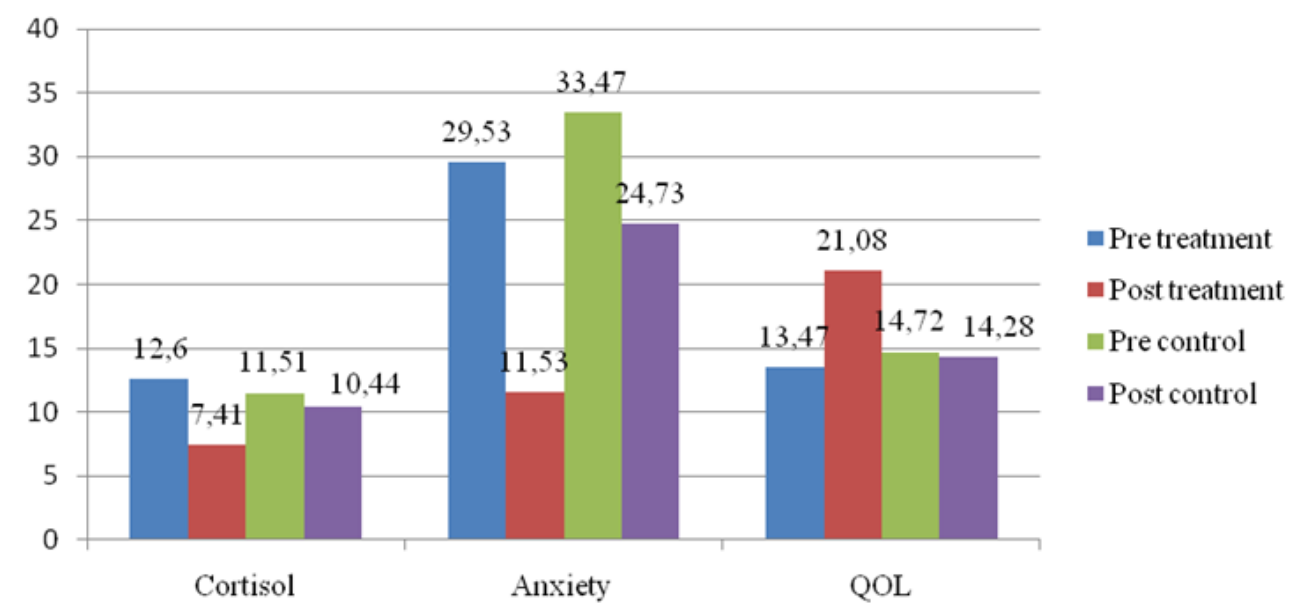

Fig. 1. Average of variables.

Table 1. Results of the different variable test in the treatment group and control group

\begin{tabular}{lcc}
\hline \multicolumn{1}{c}{ Variable } & $\mathrm{p}$ & Interpretation \\
\hline Cortisol level & 0.00 & Sig \\
Anxiety & 0.013 & Sig \\
Quality of life & 0.00 & sig \\
\hline
\end{tabular}

\section{DISCUSSION}

Psychocurative that consists of cognitive, social, spiritual and physical support is an effort that is expected to change distress conditions into eustress in an advanced stage of cervical cancer patients. It happened because psychocurative able to make cervical cancer patients adjust on their psychological conditions and situations, and build harmonious and integral relationships in order to improve their psychological stability.

In cancer patients, the main psychological problem is the fear of the disease. This fear arises because of thelack of understanding about the disease. Some researchers claim that cancer patients feel like a victim or someone who has been sacrificed then they suffer such a malignancy. The lack of support from the surroundings (social support) can also reduce the motivation of patients to survive (Soetrisno. 2009).

According to Kang et al (2009), logotherapy (similar to psychocurative) can be useful to increase the quality of life by reduces the suffer in advanced stage cancer patients. There are differences in the study, where the subjects used are adolescents with all types of the advanced stage of cancer.
Similar research that conducted by Martha (2006) used a cross-sectional study on 84 breast cancer patients, aged over 21 years, and had not received chemotherapy or radiation intervention. As a result, patients who have the meaning of a good life and close to God (good psychological well-being) have better physical and psychological responses than patients who have a low value of life $(\mathrm{p}=0.00)$. On the other hand, aspects of spirituality (including interpreting life and prayer) are stated to improve psychological and physiological responses in cancer patients.

Other researchers found that the increase ofblood serum cortisol levels was found in individuals experiencing biological or emotional stress, depression, sleep disorders, fever, hypoglycemia, anorexia nervosa, and post surgery (Young, 2004; Lovallo et al 2006).

In this study, researchers used blood serum for cortisol examination. The number and timing of blood serum collection were the same in all patients in both the treatment and control groups. Researchers used blood serum cortisol levels with consideration of cortisol secreted through a series of processes involving the hypothalamic-pituitary-adrenal axis (HPA), which is associated with circadian rhythms. The blood serum is best to describe the actual cortisol level, because the result of cortisol level on the HPA axis, is closest to blood vessel cortisol level. 
Stone (2001) in his study examined the relationship between stress and cortisol level with different samples using saliva that has the same results using the serum. Although saliva is easier to collect than blood, researchers prefer blood serum because of the various considerations above.

In this study, the treatment group subjects have the serum cortisol levels decreased, the level of anxiety decreased and quality of life increased. Based on the conclusions of this study, it is necessary to do psychocurative in advanced stage cervical cancer patients to prevent the increase of cortisol levels from avoiding distress or excessive emotional stress and pathological changes to eustress.

\section{CONCLUSION}

Blood serum cortisol level in patients with psychocurative treatment was lower than that in control group. Blood serum cortisol level in patients treated with psychocurative method was lower than that in control group. Whereas, the quality of life of patients who received psychocurative treatment was higher than that in control group.

\section{SUGGESTION}

Psychocurative that consists of cognitive, social, spiritual and physical support is given to every patient with an advanced stage of cervical cancer in addition to standard therapy (chemoradiation) by the therapist.

\section{REFERENCES}

Ancuta B, Scurtu S, Shenker M (2012). Quality of life in cervical cancer survivors. Acta Medica Marisiensis 58, 275-277

American Psychiatric Association (2013). Diagnostic and statistical manual of mental disorder. 5th Ed. Virginia, American Psychiatric Publishing, p 155-158
Andrijono (2007). Kanker serviks. Jakarta, Balai Penerbit Fakultas Kedokteran Universitas Indonesia

Azis MF (2009). Gynecological cancer in Indonesia, J Gynecol Oncol 20, 8-10

Bastaman HD (2007). Logoterapi: Psikologi untuk menemukan makna hidup dan meraih hidup bermakna. 1st Ed. Jakarta, PT Raja Grafindo Persada

Himpunan Onkologi Ginekologi Indonesia (2013). Panduan pelayanan klinik kanker ginekologi. Jakarta, Himpunan Onkologi Ginekologi Indonesia

Kang KA, Im JI, Kim HS, et al (2009). The effect of logotherapy on the suffering,finding meaning, and spiritual well-being of adolescents with terminal cancer. JKorean Acad Child Health Nus 15, 136-144

King CR, Hinds PS (2012). Quality of life: From nursing and patient perspectives. United Kingdom, Jones and Barlett Publishers

Lovallo WR, Farag NH, Vincent AS, et el (2006). Cortisol responses to mental stres, exercise, and meals following caffeine intake in men and women. Pharmacology Biochemistry and Be-haviour 83, 441447

Martha M (2006). Effect of spirituality in breast cancer survivors. Oncology Nursing Forum 33, E1-E7

Murti B (2010). Desain dan ukuran sampel untuk penelitian kuantitatif dan kualitatif di bidang kesehatan. Yogyakarta, Gajah Mada University Press

Rasjidi I (2009). Epidemiologi kanker serviks. Indonesian Journal of Cancer 3, 108

Schettler T (2013). The ecology of breast cancer: The promise of preventionand the hope for healing. Stres, Social Support, and Breast Cancer, 145-162

Sephton SE, Sapolsky RM, Kraemer HC, et al (2000). Diurnal cortisol rhythm as a predictor of breast cancer survival. J Natl Cancer Inst. 92, 994-1000.

Stone AA, Schwartz JE, Smyth J, et al (2001). Individual differences in the diurnal cycle of salivary free cortisol: A replication of flattened cycles for some individuals. Psychoneuroendocrinology 26, 295-306

Soetrisno (2009). Ekspresi Heat shock Protein60,70,90 dan kortisol pada persalinan ibu primigravida yang mendapat psikokuratif. A dissertation. Surabaya, Universitas Airlangga

Young AH (2004). Cortisol in mood disorders. Stress 7, 205-8 